\title{
Assessing Energy Policy Instruments: LNG Imports Into Saudi Arabia
}

Rami Shabaneh and Maxime Schenckery 


\section{About KAPSARC}

The King Abdullah Petroleum Studies and Research Center (KAPSARC) is a non-profit global institution dedicated to independent research into energy economics, policy, technology and the environment across all types of energy. KAPSARC's mandate is to advance the understanding of energy challenges and opportunities facing the world today and tomorrow, through unbiased, independent, and high-caliber research for the benefit of society. KAPSARC is located in Riyadh, Saudi Arabia.

This publication is available in Arabic.

\section{Legal Notice}

(C) Copyright 2019 King Abdullah Petroleum Studies and Research Center ("KAPSARC"). This Document (and any information, data or materials contained therein) (the "Document") shall not be used without the proper attribution to KAPSARC. The Document shall not be reproduced, in whole or in part, without the written permission of KAPSARC. KAPSARC makes no warranty, representation or undertaking whether expressed or implied, nor does it assume any legal liability, whether direct or indirect, or responsibility for the accuracy, completeness, or usefulness of any information that contain in the Document. Nothing in the Document constitutes or shall be implied to constitute advice, recommendation or option. 


\section{Key Points}

atural gas could play an important role in diversifying Saudi Arabia's power mix away from a heavy reliance on oil as fuel for power generation. While the country attempts to increase domestic natural gas production, supplementing domestic supply with liquefied natural gas (LNG) imports could be an option worth considering.

This paper examines the issues and implications of opening up the Kingdom's economy to LNG imports and looks at what specifications and market reconfigurations the adoption of such a policy would require.

LNG imports can provide a marginal benefit to Saudi Arabia's economy by substituting oil-based power generation. The flexibility offered by LNG contracts and regasification infrastructure provides a reliable solution to supplement domestic gas supplies.

An LNG import terminal for Saudi Arabia would best be situated on the Kingdom's west coast to help reduce the high levels of liquid fuel use in western and southern areas of the country. This study used an optimization modelling tool to show that our base case scenario of a 5 million tonnes per annum (mtpa) LNG import terminal on the west coast would facilitate cost-effective access to nearby LNG export regions, such as eastern Africa's Rovuma Basin and parts of the eastern Mediterranean.

The high import scenario (25 mtpa) sees more LNG imports from the Rovuma Basin, Yemen (assuming project restart) United States and Russia, without a significant uptick in landed prices. This reflects a global LNG market that is supply-elastic and can accommodate high volumes of imports beyond the mid-2020s.

Saudi Arabia's electric load profile is highly seasonal, experiencing peaks during the hotter summer months caused by the increased use of air conditioning units. This is counter-cyclical to major LNG importers in the northern hemisphere and offers a value proposition for importing LNG during the summer, when prices are lower.

Enabling LNG imports into Saudi Arabia could further develop Saudi Arabia's gas markets: it would introduce a gas benchmark price, necessary for domestic gas market reform. 


\section{Summary}

N atural gas is already playing a prominent role in diversifying Saudi Arabia's power mix away from a heavy reliance on oil-based fuels. Between 2010 and 2017, the share of natural gas used in power generation in Saudi Arabia grew from $44 \%$ to $54 \%$. The country's gas fields are being developed to increase domestic gas supplies. However, imported liquefied natural gas (LNG) could remedy the near-term scarcity of gas from domestic sources and provide the support needed to integrate more renewable and other alternative sources of energy into the country's power mix. Developments in global gas markets in recent years, including procurement and technological innovations in LNG, have unlocked value for producers and consumers.

Liquid fuels are predominately burned in western and southern Saudi Arabia, due to the limited availability of gas supplies there and constraints on the infrastructure used to transport gas from the country's eastern fields. An LNG import terminal on the Kingdom's Red Sea coast could circumvent the constraints in Saudi Arabia's Master Gas System and free up crude and other oil products for export.

Saudi Arabia's electricity load profile is ideally suited for taking advantage of lower LNG prices in the northern hemisphere summer. Europe and Northeast Asia are currently the biggest importers of LNG globally, where gas sells at a premium during the winter months due to its primary use as a heating fuel. Gas demand in Saudi Arabia, on the other hand, peaks during the summer to meet the increased air conditioning load. Furthermore, chartering floating storage and regasification units (FSRUs) offers a reliable and cost effective option for seasonal imports, reducing the need to burn large volumes of liquid fuels. Nexant's World Gas Model indicates that opening up Saudi Arabia's economy to LNG imports by 2021 would attract flows of seaborne gas from Africa's northern and eastern regions, the United States and Russia, among others, depending on the scale of imports.

Previous KAPSARC publications, and this paper's calculations, show that displacing oil with LNG could benefit the Saudi economy in several ways. The advantage of LNG, as its market continues to grow, is that it has the flexibility and scalability to adapt to existing energy development initiatives in the Kingdom, including domestic gas development, renewable energy and nuclear power. Imported LNG can also insure against delays or changes in developing other domestic energy resources. In addition, importing LNG at international prices can provide a pathway toward a more robust deregulated market structure, helping to further develop demand for domestic gas and incentivizing the production of higher cost gas fields. 


\section{The Role of Natural Gas in Saudi Arabia's Power Mix}

$\mathrm{N}$ atural gas consumption in Saudi Arabia represents $37 \%$ of the country's primary energy demand (BP 2018). The power sector is the country's largest gas consuming sector, responsible for about two-thirds of the Kingdom's total gas demand, followed by the industrial and petrochemical sectors. The Kingdom's growing need for power has strained domestic natural gas supplies. As a result, local utilities are using large amounts of liquid fuels for power generation to meet the rising demand for electricity. As Figure 1 shows, liquid fuels - crude oil, heavy fuel oil (HFO), and diesel - account for around half of all fuels used for electricity generation; their use is closely linked to the availability of natural gas. In 2017, Saudi Arabia burnt 1,958 trillion British thermal units (Btu) of liquid fuels, or almost 890 thousand barrels per day $(\mathrm{Mbbl} / \mathrm{d})$, in order to generate power.

Despite having the sixth largest proven natural gas reserves in the world (BP 2018), Saudi Arabia's natural gas production has yet to reach its full potential. Associated gas from crude production accounts for most of the country's gas supplies (EIA 2017). Due to the Kingdom's rapid gas demand growth, Saudi Arabia's national petroleum and natural gas company, Saudi Aramco, has targeted an increase in the production of gas from non-associated gas fields in Karan, Hasbah, and Arabiyah. Between 2007 and 2017, gas production in Saudi Arabia grew from 70.7 billion cubic meters $(\mathrm{bcm})$ to $111.4 \mathrm{bcm}$, averaging 4.4\% growth per annum (BP 2018).

Figure 1. Yearly fuel consumption of power and seawater desalination, by type.

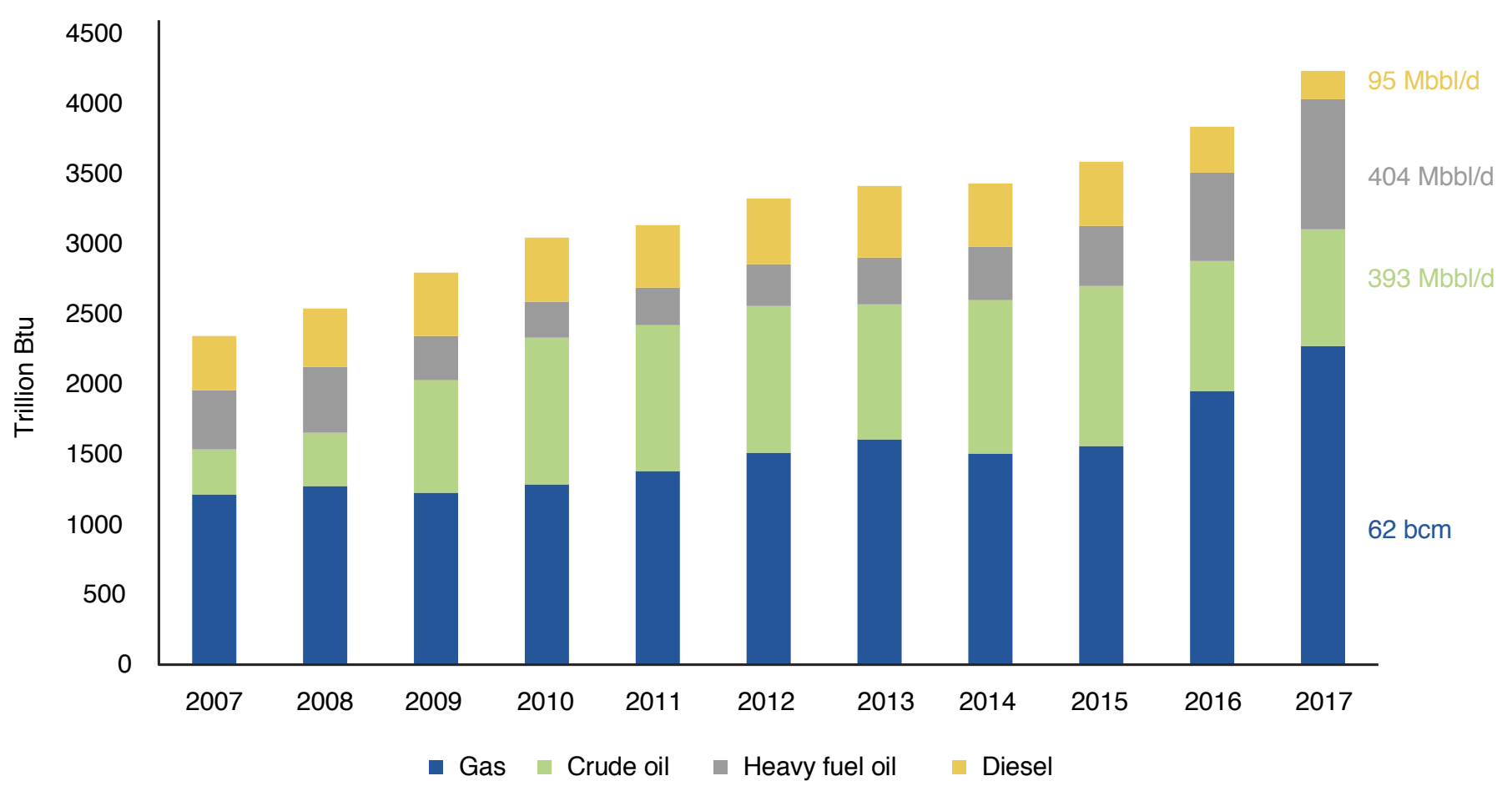

Source: Electricity \& Cogeneration Regulatory Authority (ECRA), KAPSARC 2018. 
Meanwhile, rapid growth in domestic power demand, driven mainly by population growth and industrial development, has increased the demand for crude oil and other liquid fuels to make up for the shortfall in the country's gas supply. Historically, low electricity tariffs - especially non-industrial tariffs - have also contributed to the residential sector's high energy consumption. Fuel and electricity price reforms and new energy efficiency standards for buildings and equipment aim to temper this power demand growth. However, the Saudi Electricity Company (SEC), Saudi Arabia's largest utility, expects peak load demand to double by 2030 (AISaggaf 2018), as shown in Figure 2. Given this expected growth in future power demand, maintaining the status quo in the power mix implies the increased use of crude oil and oil products as fuels for electricity generation. This would result in a large opportunity cost from the reduced quantity of domestically produced crude oil available for export.

There are plans to increase Saudi Arabia's domestic raw natural gas production within the next decade from 145 bcm in 2018 to 238 bcm by 2030 (Energy Intelligence 2018). This target is plausible: Saudi Aramco raised its gas output by a similar multiple (1.5 times) between 2007 and 2017. However, new gas supplies in the Kingdom will not come from associated gas, as has historically been the case. Rather, there has been a shift toward developing more non-associated, more sour, and more unconventional gas fields, which together bring with them a set of challenges, including higher costs. New and proposed expansions of the

Figure 2. Peak load demand is expected to increase.

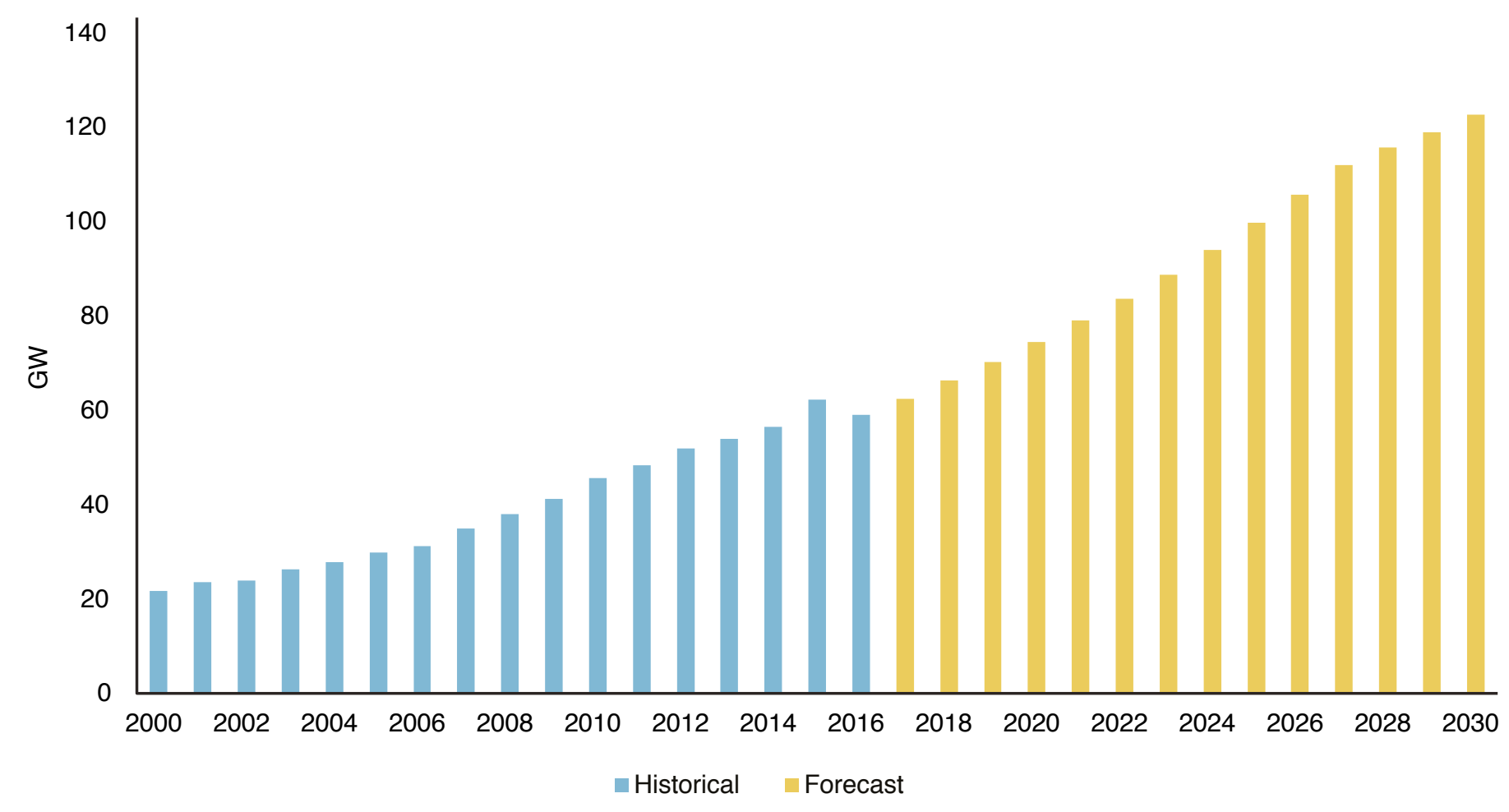

Source: Saudi Electricity Company. 
Fadhili, Hawiyah and Midyan processing plants will accommodate over $36 \mathrm{bcm}$ of additional raw gas supply. This will mostly be sourced from the Hasbah (phase 2), Khursaniyah, Midyan, Hawiyah, and Hardh gas fields over the next few years, but other new sources of supplies will be required beyond that timeframe. The development of Saudi Arabia's unconventional gas reserves is ongoing in the Northern Arabian field (Turaif), at South Ghawar, and in the Jafurah Basin. International oil field services company Baker Hughes has estimated the Kingdom's technically proven shale gas reserves amount to some 645 trillion cubic feet - about double the quantity of proven shale gas reserves in the United States (U.S.) (Elass 2018). Saudi Aramco is currently targeting the production of $31 \mathrm{bcm}$ of marketable gas supplies from unconventional sources by 2030 (Energy Intelligence 2018). However, in order to take full advantage of its shale gas potential, Saudi Arabia will need to address technology transfer, water scarcity, and workforce concerns.
Given the lengthy and difficult process of developing new domestic gas resources, LNG imports could be a useful policy instrument for Saudi Arabia to consider. The LNG market has grown significantly over the past decade, with new LNG suppliers emerging, such as Australia, the U.S. and Russia. Shorter term and destination-variable sales contracts are providing buyers with greater flexibility and an alternative to the traditional oillinked long-term LNG contracts, further helping to increase the appetite for LNG in some markets. Under certain market configurations, LNG could add value to Saudi Arabia's economy by freeing more domestically produced crude oil for export (Blazquez, Manzano and Lester et al. 2018). While the government of Saudi Arabia has not yet indicated any plans to import LNG, this paper assesses how such a policy could play out. It investigates how LNG imports could complement and support other policies and initiatives in the Kingdom, including domestic energy market developments and energy efficiency measures. 


\section{Seasonality in Power Demand and Natural Gas Profile}

$\mathbf{R}$ esidential electricity demand accounts for almost $50 \%$ of Saudi Arabia's annual power

consumption due to the high air conditioning load during the summer months - space cooling accounts for over $70 \%$ of the power used in the residential sector (ECRA 2011). As Figure 3 shows, the peak load demands in the eastern, central and western areas, as defined by the Saudi Electricity Company (SEC) in Figure 4, are generally similar in nature because the bulk of the country's population and industrial cities are concentrated in these areas. The less populated southern area of the country consumes about $75 \%$ less power on average than each of the three other areas. However, energy demand in all four areas peaks during the summer months, i.e., roughly from April through October.

As previously mentioned, crude oil, diesel and heavy fuel oil meet the demand from the Kingdom's thermal power generation sector when natural gas is unavailable. As such, demand for crude oil peaks during the summer months in order to meet the spike in air conditioning load. However, the use of liquid fuels in power plants varies across the country's four main areas.

The western and southern areas of the country burn the biggest quantity of liquid fuels (Figure 5). The Master Gas System (MGS), a country-wide gas transportation network completed in 1982, carries gas via pipelines from Saudi Arabia's eastern gas fields, where the country's gas reserves are concentrated, to other areas of the Kingdom. However, this distribution system's effectiveness is compromised by high demand in the eastern area of the country and infrastructure bottlenecks, limiting the amount of natural gas that can be transmitted via the MGS.

Figure 3. Monthly average load variation in Saudi Arabia by area, 2017.

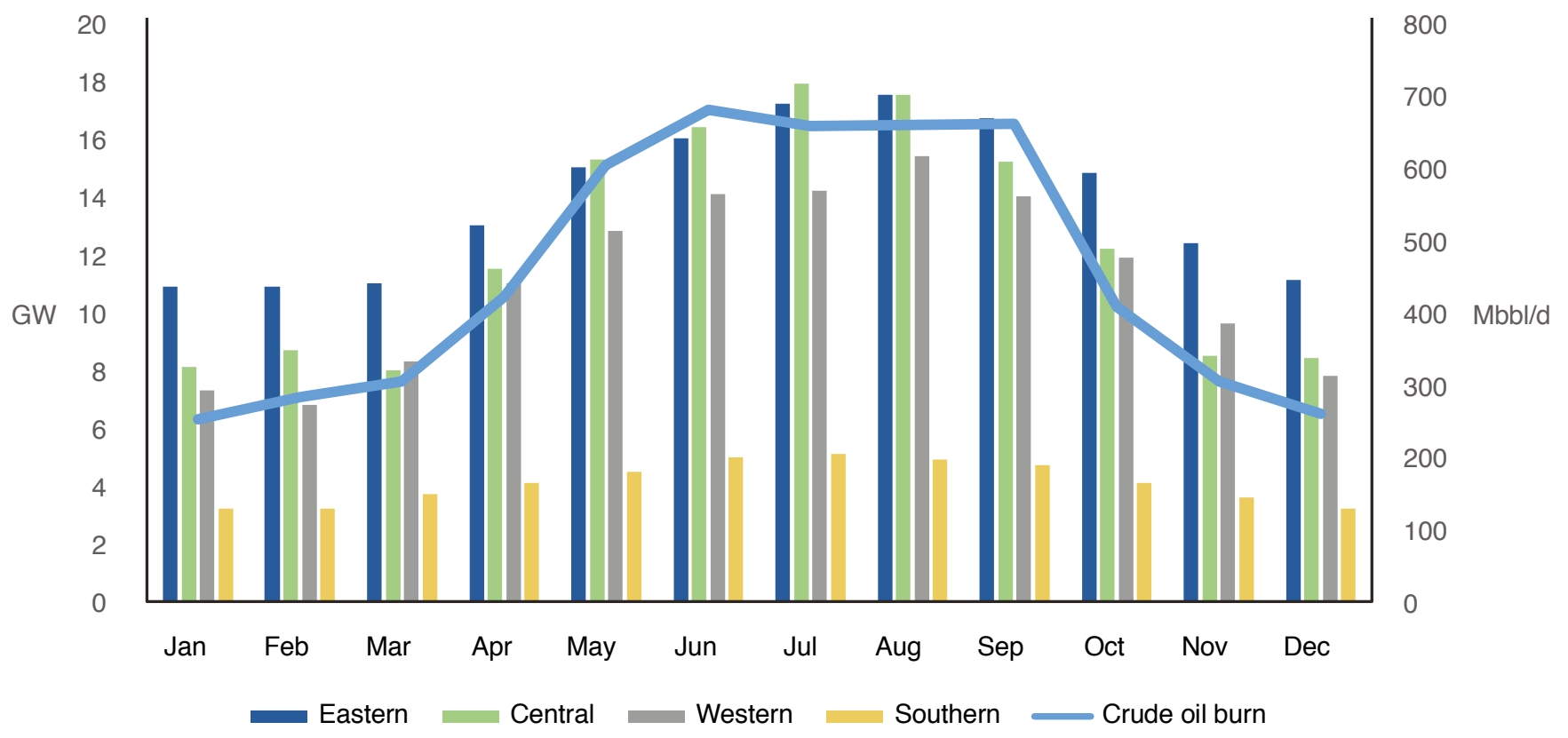

Source: ECRA, JODI (2018). 
Figure 4. Saudi Arabia oil and gas infrastructure, and SEC operating areas.

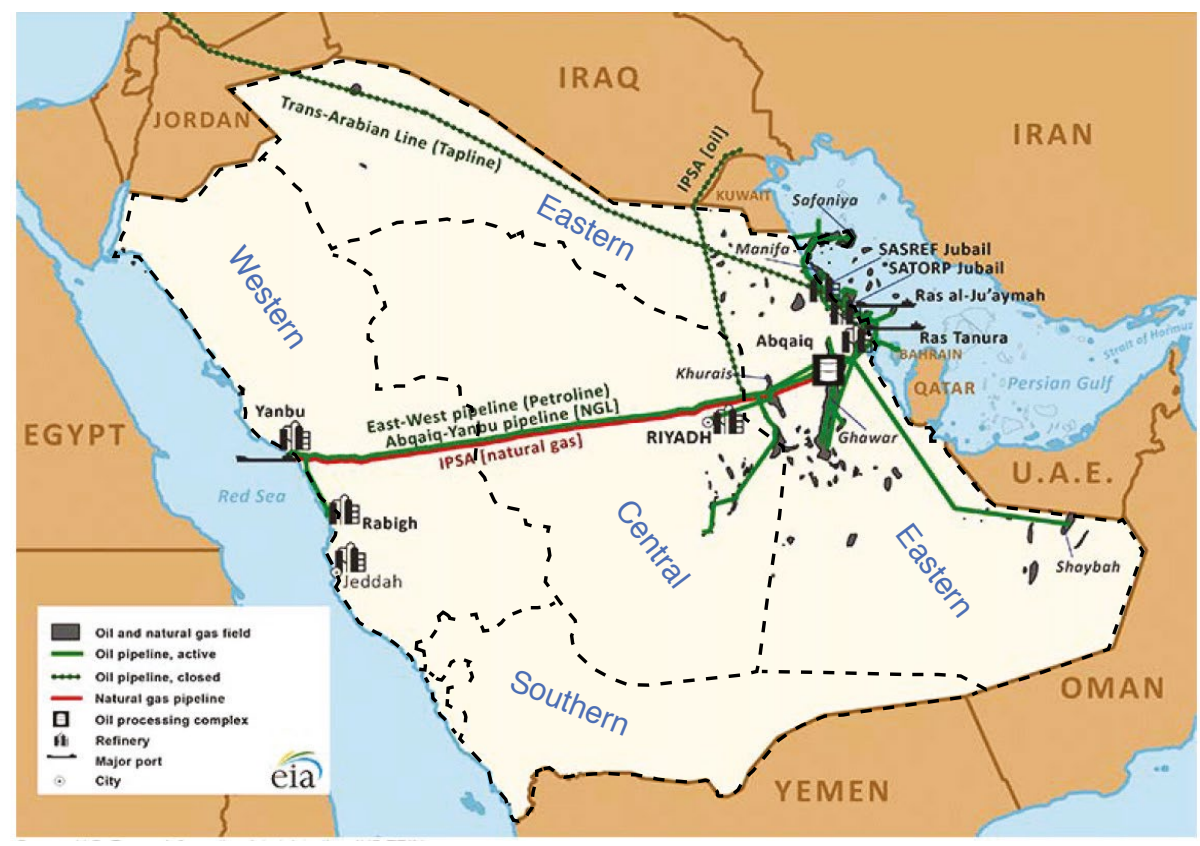

Source: EIA, SEC.

Figure 5. Distribution of annual fuel consumption by area, 2017.

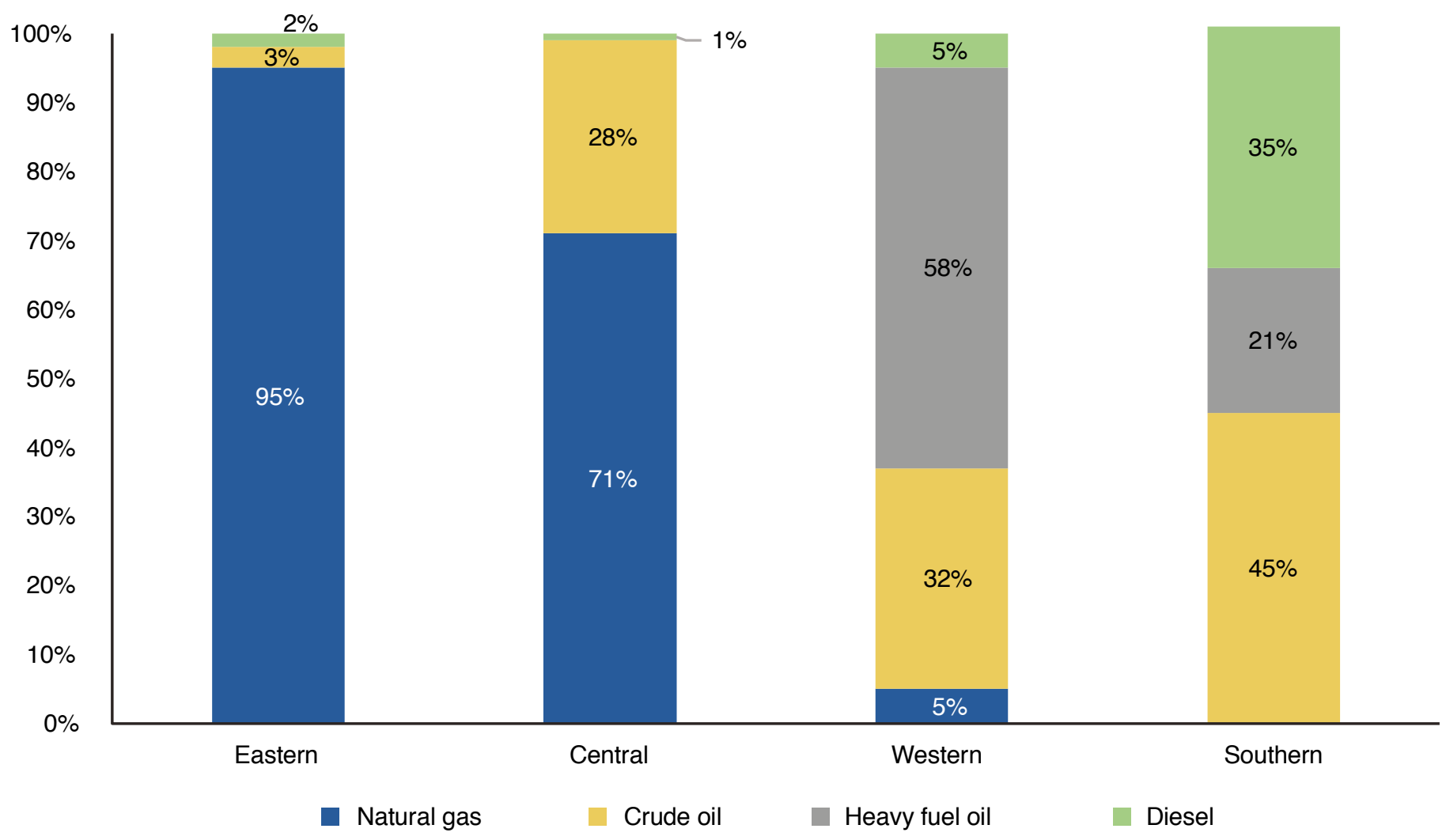

Source: ECRA. 
More liquid fuel is burnt in the west of the country than in the east. An LNG import terminal located on Saudi Arabia's Red Sea coast could therefore help meet western regional demand and mitigate infrastructure constraints in the MGS.

We model the Kingdom's natural gas market in all its components through the framework illustrated in Figure 6, with Region A representing Saudi Arabia's energy market equilibrium for power generation and Region B representing the international LNG market equilibrium. The two regions could be connected to facilitate trade, but are not now linked. Region A currently has less supply, relative to demand, than Region B. The majority of the supply is low-cost associated gas (produced as a by-product of crude oil extraction), but its quantity is limited. Shifting production toward more non-associated gas raises the cost of the gas supply. The lack of sufficient low- cost gas supply currently forces electric utilities to use crude oil and oil products, at a high opportunity cost to the country, given the international price of crude oil.

Without LNG imports (absent the ability to trade), the power market in Region A clears at the international opportunity cost of oil.

However, with LNG imports, the price clears at the total cost of imported LNG. Domestic supply quantity develops until the delivered cost equals the LNG delivered cost. A market reflecting the real price for natural gas is created, reflecting the international LNG market's supply and demand balance as well as the cost of domestic production.

Price movements in Saudi Arabia and in the global LNG market will depend on the relative elasticity

Figure 6. Supply curve for power generation including international LNG trade.

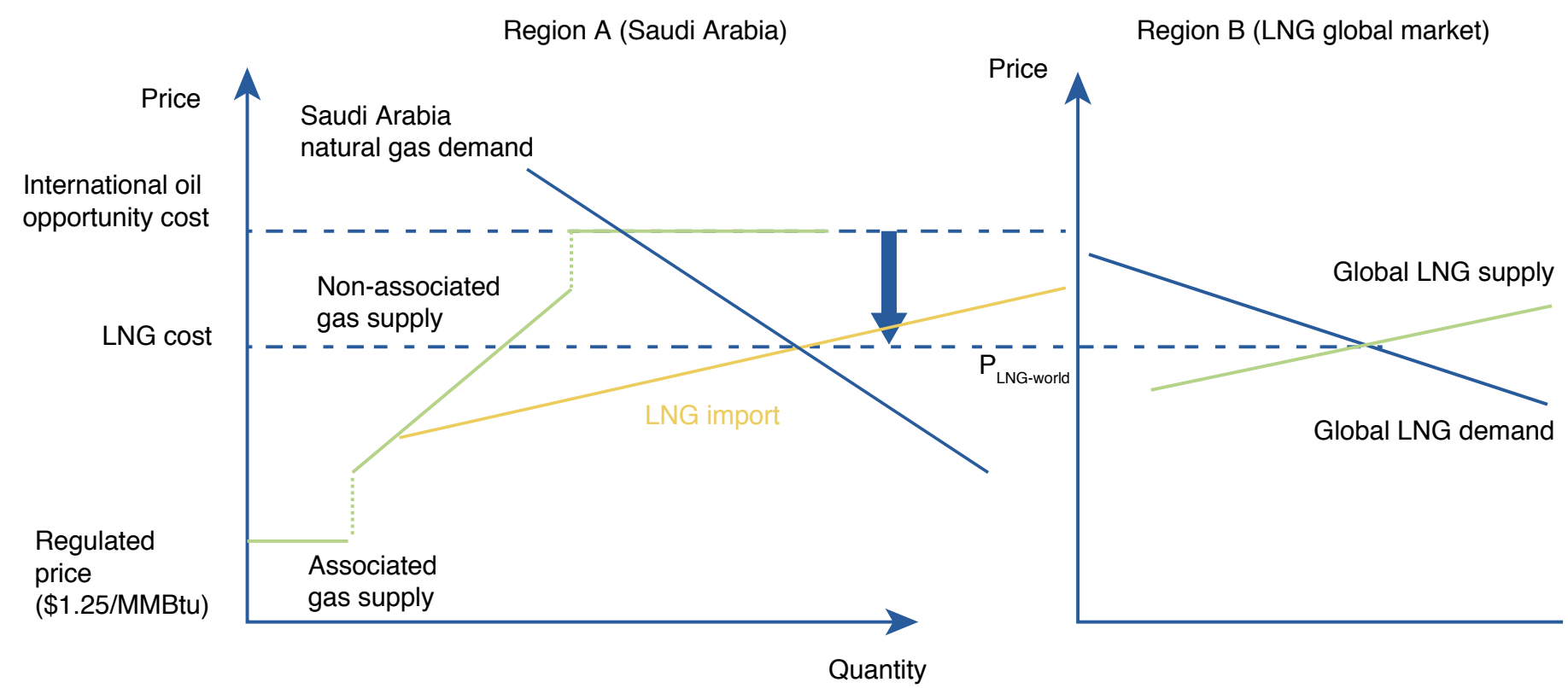

Source: KAPSARC. 
(price responsiveness) of supply and demand, which will also determine the amount of trade that occurs and the infrastructure required. LNG imports could bring flexibility to Saudi Arabia's energy system while enabling domestic gas supply development according to global natural gas market signals.
Using imported LNG imports for power generation in Saudi Arabia could provide a cheaper option than using oil. Importing LNG could also improve the country's energy security and adaptability to uncertainty as it transitions its energy mix. 


\section{Simulating the Consequences of LNG Imports Into Saudi Arabia}

W e use Nexant's World Gas Model (WGM), a partial equilibrium model, specified as a linear programming problem (Nexant 2018) to determine the possible and optimal sources of LNG for import into Saudi Arabia. The WGM has a dynamic nature: it considers a long time horizon (2040) further decomposed using a quarterly time resolution. The representation used in the model includes all countries that produce, consume and transit natural gas. Each country is modeled as a given node. There is an exogenously-determined demand level at each consuming node that is posited to be purely price inelastic.

The model decision variables represent the supply and trade flows of natural gas to meet the input demand figures. Overall, the model minimizes the total cost of all the components of the global gas supply chain: extraction, pipeline and LNG transportation, and underground storage. The solution is optimized subject to a set of linear constraints, including balancing the supply and demand equation at each node for each period, infrastructure capacity, and contractual restrictions. As is usual with this type of linear programming problem, the shadow variable associated with each node, at a given period, provides the marginal cost to supply gas at that node at that time. This marginal cost can be interpreted as the equilibrium price of natural gas that would prevail if the market were perfectly competitive at that time.

The model is calibrated using Nexant's proprietary database, KAPSARC data, and the authors' analysis of aspects of the Saudi Arabian and world energy system that typically determine the trajectory of future demand levels at the consuming nodes, the costs and capacities at the extraction nodes, and infrastructure characteristics. To assess the potential of LNG imports into Saudi Arabia using the WGM, we create two cases for a supply deficit building up to 2035: a $6 \mathrm{bcm}$ base case and a $30 \mathrm{bcm}$ high case (Table 1). The base case assumes an import terminal within the range of those in neighboring Middle Eastern countries such as Kuwait and Egypt. The high case assumes that Saudi Arabia replaces almost all of its liquid fuel usage in power plants with LNG. The high case also allows us to build a cost stack of multiple LNG supply sources to meet the highest potential demand for gas in the Kingdom.

The western coast of Saudi Arabia presents the best location for an LNG import terminal due to the proximity of power plants and water desalination facilities that now rely on liquid fuels. An import node was created in Jeddah along one of the main global shipping routes that includes the Suez Canal. The choice of a terminal in Yanbu, or any other port location along this coast, does not change the model's results. All LNG routes and distances were calculated from each existing and planned export terminal into the Saudi receiving port (Marine Traffic 2018).

Our analysis of the receiving and regasification terminal includes a comparison of a floating storage and regasification unit (FSRU) and an onshore terminal. The former was selected for its flexibility, speed of deployment and cost competitiveness. FSRUs have lower upfront costs (typically 60\% of the cost of an onshore terminal) and can accommodate seasonal demand. In Kuwait, a modified vessel is deployed as an FSRU and used for nine months of the year to import LNG. In the remaining three months the same vessel can be used for short term carrier operations (King \& Spalding LLP 2015). The investment it requires is also reversible - 'stranded assets' do not occur if 
LNG imports are only required on a short-term basis (Songhurst 2017). We use FSRUs to build our Saudi case because they present lower upfront costs and because LNG imports may only be a transitional measure for the Kingdom.

This analysis uses the WGM's cost assumptions for Kuwait's FSRU as a benchmark. Taking into account the lead time needed to plan, construct and deliver the FSRU along with the related onshore infrastructure, the model assumes that Saudi Arabia starts importing LNG in 2021. Neither case accounts for the cost of inland infrastructure and connectivity. As such, while the increased use of FSRUs could provide economies of scale, we assume the same fixed and variable costs in both cases.

The WGM includes price forecasts for crude oil and some refined oil products, as well as coal and carbon prices for North America, Europe and Asia. The model assumes a long-term oil price of $\$ 85$ per barrel (bbl) (see Appendix 1) which was left unchanged.

Trade restrictions are exogenous to the WGM. There is currently no trade between Iran, Israel and Qatar, countries that hold a significant amount of natural gas reserves. To reflect the present circumstances, the restrictions were inserted for the forecast period for LNG trade. The civil war in Yemen forced the 6.5 mtpa Yemen LNG to declare force majeure in April 2015, and it has remained offline since. However, no damage has occurred to the liquefaction units and the WGM assumes exports to resume by 2022.

Table 1. Assumed characteristics and costs for the FSRU.

\begin{tabular}{c|c|c|c|c|c|c|c} 
Location & $\begin{array}{c}\text { Import } \\
\text { requirement } \\
(\mathrm{bcm})\end{array}$ & $\begin{array}{c}\text { Nominal } \\
\text { capacity } \\
(\mathrm{mtpa})\end{array}$ & $\begin{array}{c}\text { Nominal } \\
\text { capacity } \\
(\mathrm{bcm})\end{array}$ & $\begin{array}{c}\text { Number of } \\
\text { FSRUs }\end{array}$ & $\begin{array}{c}\text { Assumed } \\
\text { start year }\end{array}$ & $\begin{array}{c}\text { Fixed cost per } \\
\text { unit }(\$ / \mathrm{MMBt})\end{array}$ & $\begin{array}{c}\text { Variable } \\
\text { cost per unit } \\
(\$ / \mathrm{MMBtu})\end{array}$ \\
\hline \multirow{2}{*}{$\begin{array}{c}\text { Port of } \\
\text { Jeddah }\end{array}$} & 6 & 5 & 6.8 & 1 & 2021 & 0.27 & 0.51 \\
\cline { 2 - 8 } & 30 & 25 & 34 & 5 & 2021 & 0.27 & 0.51
\end{tabular}

Source: KAPSARC. 


\section{Results: Optimal Supply and Pricing}

$\mathrm{n}$ the base case scenario of $6.8 \mathrm{bcm}$ (5 mtpa), LNG imports into Saudi Arabia come mainly from Egypt and the Rovuma Basin in eastern Africa (Mozambique and Tanzania) (Figure 7), due to their proximity to Saudi Arabia. The development of export infrastructure from these two areas of gas production coincides with the start of LNG imports into the Kingdom in the model. Interestingly, when running the model assuming that the current restriction of flows from Qatar to Saudi Arabia has been lifted, the model clears without any imports from Qatar. This is due to the high transportation cost of transporting LNG from Qatar offsetting its lower cost of supply.

The shadow price of $L N G$ in Saudi Arabia increases from about \$7.3/MMBtu in 2023 to around \$9.5/MMBtu in 2035. This increase in price reflects the model's assumption that natural gas is exhaustible, with the least expensive gases tapped first. The delivered price of LNG includes the cost of gas, liquefaction, transportation and regasification. This cost also reflects the structure of the contracts: a mixture of spot prices and oil indexed prices.

Almost $72.5 \mathrm{bcm}$ (or $53 \mathrm{mtpa}$ ) of LNG projects from eastern Africa are slated to come online by 2035 , according to WGM assumptions. This suggests that the Rovuma Basin could be a key supplier to Saudi Arabia if the latter chose to further expand its imports after that date. Furthermore, even if LNG exports from Egypt are restricted over the long run (with priority given to growing domestic demand), other new gas projects in the Mediterranean, such as those offshore Cyprus, could potentially supply Saudi Arabia with LNG.

Figure 7. Model simulation of LNG imports into Saudi Arabia under the 6 bcm scenario.

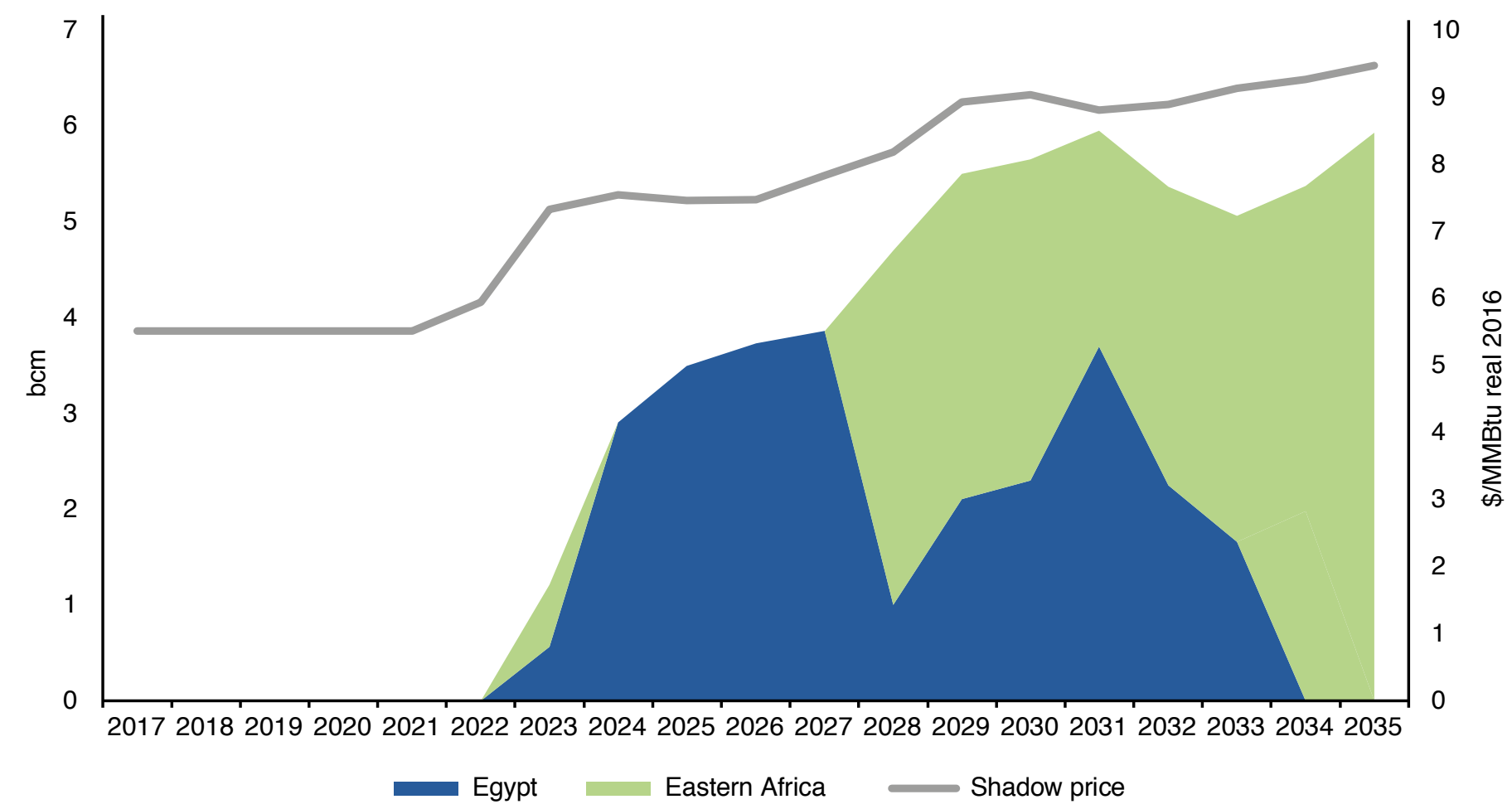

Source: KAPSARC based on WGM run - March 2018. 
Eastern Africa continues to play a significant role in supplying LNG to Saudi Arabia in the $30 \mathrm{bcm}$ scenario (Figure 8), accounting for up to $76 \%$ of Saudi imports. Other suppliers in the model include Yemen, Russia, and the U.S.

Under the $30 \mathrm{bcm}$ scenario, shadow prices for Saudi Arabia rise to $\$ 10 / M M B t u$ by 2035 . This does not show a significant difference from our base case price range which reflects a high elasticity of LNG supply beyond the 2020s. The model shows, however, a slight increase in prices in 2029 and 2030 as lower cost cargoes from Yemen and Egypt temporarily divert to accommodate new demand in South Asia and parts of the Mediterranean, respectively. Despite this, the competitive nature of the global LNG market represented in the model and the implied elastic supply curve could enable
Saudi Arabia to accommodate large fluctuations in domestic natural gas demand by importing LNG, without significantly affecting the cost of supply. Eastern Africa's Rovuma Basin, where gas was first discovered in 2010, contains an estimated 188 trillion cubic feet (5.3 trillion cubic meters) of proven and probable gas reserves (IHS Markit 2017).

This makes the basin one of the most promising new gas plays in the world. However, by the time of writing and model simulation, the only project in the prospect to have reached final investment decision status is Italian oil and gas company Eni's 3.3 mtpa, \$8billion, Coral South floating liquefied natural gas (FLNG) facility offshore Mozambique. Many eastern African project delays can be traced back to the drop in oil and gas prices in mid-2014, which threatened the economics of remotelylocated greenfield projects. Local institutional

Figure 8. Model simulation of LNG imports into Saudi Arabia under the $30 \mathrm{bcm}$ scenario.

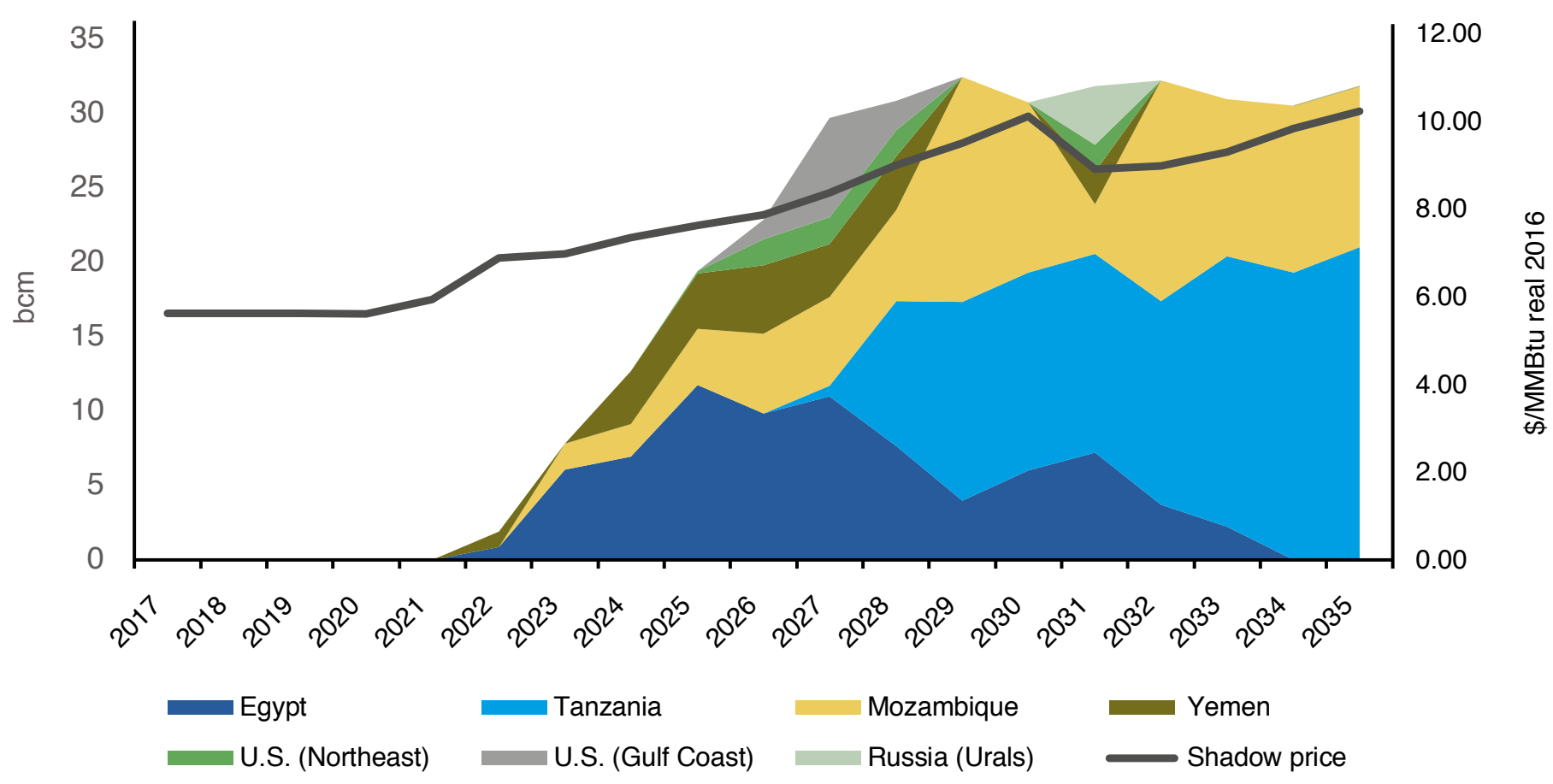

Source: KAPSARC based on WGM run - March 2018. 
challenges have also created many political hurdles for development plans (Schenckery et al. 2018). We ran a scenario to understand the likely supply alternatives, in which the risks of eastern African projects were assessed and deferred until after 2030, except for Coral South FLNG.

In this scenario, the roles of the U.S. and Russia's Ural region (including Yamal and Arctic LNG 2) become more prominent, in addition to cargoes from West Africa as a consequence (Figure 9).

Delays in eastern Africa LNG projects could cause prices to rise, as shown by the shadow price peaking at close to $\$ 12 / \mathrm{MMBtu}$ in 2030 before dropping back to normal levels as eastern African projects come online.

\section{Simulation factoring in seasonality}

As Figure 3 illustrates, Saudi Arabia's load profile is highly seasonal and counter-cyclical to the global LNG market. Peak demand for LNG globally usually occurs during the northern hemisphere winter, when demand for heating peaks.

By default, the WGM shows a flat gas demand profile throughout the year for Saudi Arabia that satisfies all residential, commercial and industrial sectors. However, as Table 2 shows, the load profile in Saudi Arabia is heavily weighted to the second and third quarters of the year, reflecting Saudi Arabia's energy demand for cooling during the

Figure 9. Model simulation of LNG imports into Saudi Arabia under the $30 \mathrm{bcm}$ scenario with risked projects from eastern Africa.

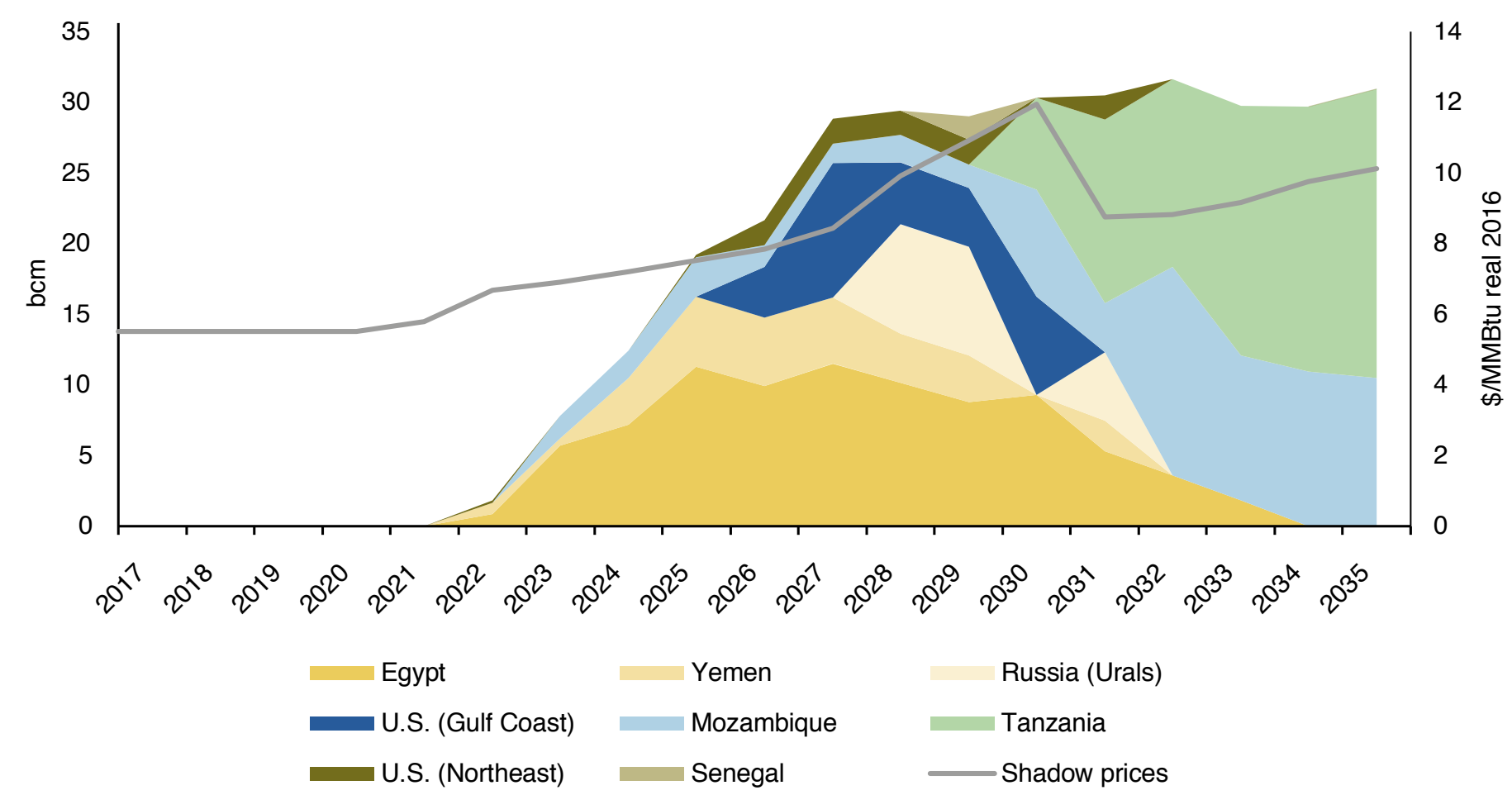

Source: KAPSARC based on WGM run - March 2018. 
Table 2. Quarterly load profile for Saudi Arabia in 2015.

\begin{tabular}{c|c|c|c} 
Q1 (Jan, Feb, Mar) & Q2 (Apr, May, Jun) & Q3 (Jul, Aug, Sep) & Q4 (Oct, Nov, Dec) \\
\hline $19 \%$ & $27 \%$ & $31 \%$ & $23 \%$
\end{tabular}

Source: KAPSARC based on ECRA data.

Figure 10. LNG imports with a seasonal demand profile in Saudi Arabia.

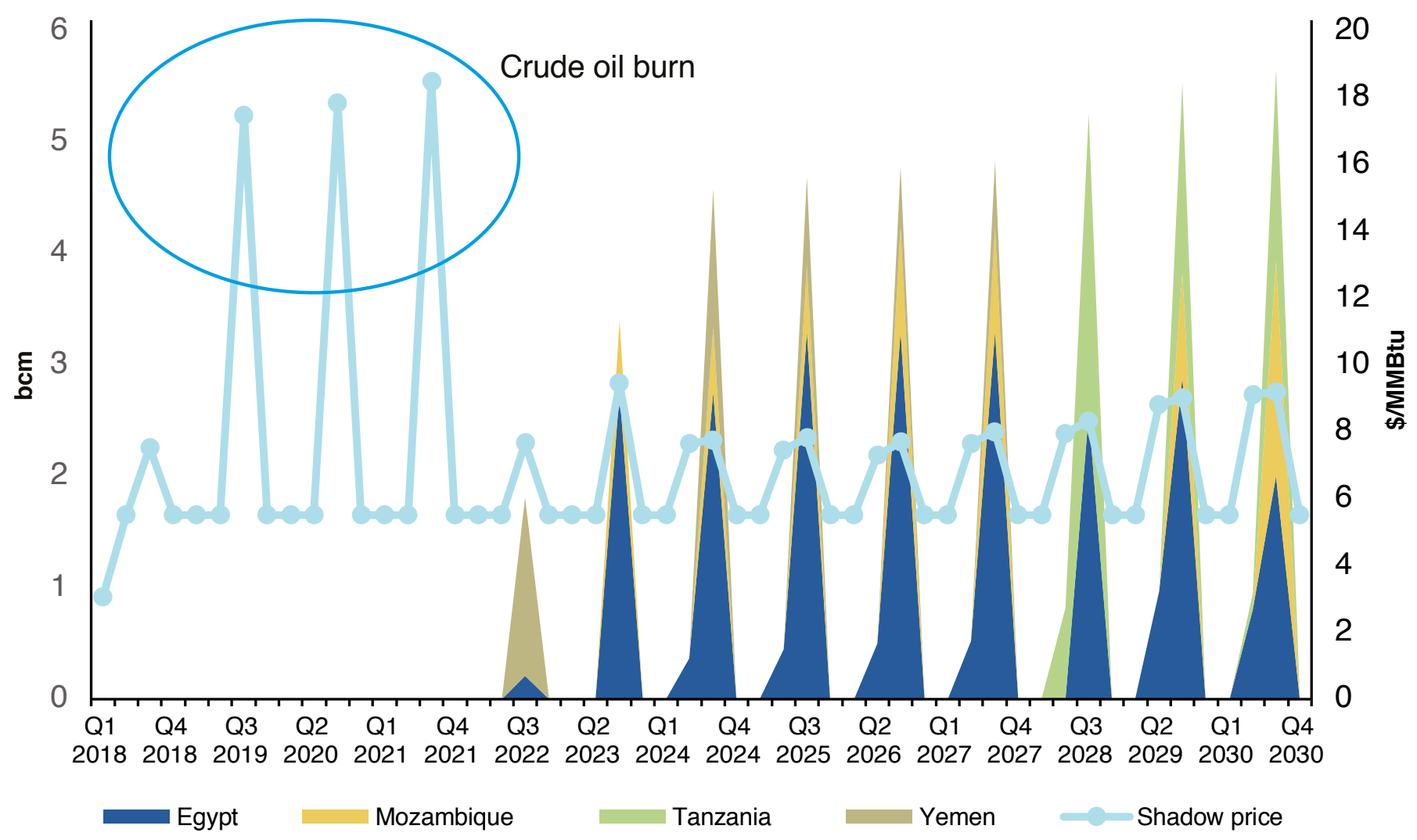

Source: KAPSARC based on WGM run - March 2018. 
summer months. We therefore adjusted the Saudi Arabian gas demand profile in WGM to reflect this seasonal profile.

Running the base case scenario (5 mtpa or $6.8 \mathrm{bcm}$ ) with seasonality displays a more realistic picture of the current situation in Saudi Arabia. As Figure 10 shows, prices spike during the summer months, reflecting the higher opportunity cost of burning crude oil. However, once imports of LNG begin in 2021, shadow prices soften and drop to reflect the long-run marginal supply of LNG.

When we introduce seasonality into the model, it calls on Yemen to fill the demand gap assuming Saudi Arabia has bought all the LNG it can from Egypt and eastern Africa. This contrasts with the first scenario which shows demand without seasonality. This is due to a mismatch between supply from eastern Africa and Egypt and Saudi Arabia's demand profile. In other words, Egypt and eastern Africa's LNG capacities do not meet Saudi Arabia's total demand in the summer, forcing the model to call upon other sources of supply.

It is clear from Figure 10 that Saudi Arabia only imports LNG during the summer months because it can meet demand from domestic gas supplies during the winter. Consequently, if Saudi Arabia did start to import LNG, it would be sensible to only contract LNG volumes seasonally, as Kuwait does, from April to October. This provides opportunities for Saudi Arabia to invest in LNG projects in nearby new gas production areas, such as eastern Africa. This could be done jointly with winter-season importers or with trading houses. The advantage of the latter is that volumes could be shared or swapped, reducing costs. 


\section{Opportunities for LNG to add value to Saudi Arabia}

Whe operating heat rate for natural gas plants, particularly combined cycle plants, is lower than petroleum-based power generation (EIA 2018), indicating a net advantage for natural gas. According to the literature (Blazquez, Manzano and Lester et al. 2018), this is also true of Saudi Arabian power generation. We used the EIA heat rate for 2017 in our calculations. In Table 3, we only consider crude oil, not HFO or diesel, despite these liquids being used as fuel in Saudi Arabia's power generation industry, as previously noted.

Under the current regulated price framework, electric utilities in Saudi Arabia purchase oil at $\$ 6.35 / \mathrm{bbl}$ (\$1.11/MMBtu) and natural gas at \$1.25/ MMBtu (APICORP 2018). Regulated prices also discouraged investment in higher efficiency gas plants making oil-fired power plants more competitive. In the event of oil abundance and a low oil price, power generation would be an obvious outlet for spare oil production (absent carbon neutrality requirements).

However, Table 3 shows that in a deregulated market using international pricing, assuming a long term price for oil of $\$ 85 / \mathrm{bbl}$, the use of $L N G$ for power generation becomes more competitive than burning crude oil.

Our global market-based scenarios determine that LNG imported into Saudi Arabia is competitive against crude oil at $\$ 85 / \mathrm{bbl}$ and $\$ 55 / \mathrm{bbl}$. Oil-indexed LNG contracts remain competitive against oil at any price due to the lower heat rates of combined cycle power plants. New schemes with fixed costs, as proposed by the U.S.-based natural gas company Tellurian, remain competitive against oil at $\$ 35 / \mathrm{bbl}$.

The cost of electric power generated using LNG at the import market prices determined in our scenarios is always competitive against the price of oil. If LNG is bought from the U.S. or through oilindexed contracts, gas remains more competitive than crude oil as a fuel for power generation. LNG is an acceptable alternative to burning oil for power generation, as shown in Table 3. According to Saudi Arabia's SEC, gas is also more competitive than oil when considering levelized cost of electricity (AlSaggaf 2018).

Integrating Saudi Arabia into the global natural gas market could provide value beyond the economic benefits that could derive from such integration. Demand-side alternatives to fixed, onshore regasification terminals, such as FSRUs, are helping to seed new markets and are offering more flexibility around LNG consumption. The scalability of LNG and flexibility in chartering FSRUs means that LNG supply can be scaled up or scaled down according to the availability of domestic energy supply, whether that be from gas or renewable technologies. Chartering an FSRU on a short- to medium-term basis reduces the risk of stranded assets and provides greater flexibility than building costly, fixed onshore regasification terminals, as any rental commitment on an FSRU can be reversed in a matter of months.

LNG imports could also help diversify Saudi Arabia's energy portfolio and insure against changes in or delays to the Kingdom's domestic gas development, gas infrastructure expansion, or renewable and alternative energy deployment. Saudi Arabia could leverage the flexibility of LNG to help transition its energy mix away from a reliance on oil more smoothly and at a lower cost than would be the case if it were to continue relying on liquid fuels. Many importers of Saudi Arabia's crude oil and refined products are also growing LNG consumers. Hence, with more destination-free contracts, Saudi Arabia 
Table 3. Variable cost of electric power generation under different price scenarios.

\begin{tabular}{|c|c|c|c|}
\hline \multicolumn{2}{|l|}{ Heat rate for crude oil power plant (MMBtu/MWh) } & 10.20 & \\
\hline \multicolumn{2}{|l|}{ Heat rate of simple cycle gas plant (MMBtu/MWh) } & 10.35 & \\
\hline \multicolumn{2}{|c|}{ Heat rate for natural gas combined cycle plant (MMBtu/MWh) } & 7.65 & \\
\hline \multicolumn{2}{|l|}{ Barrel to MMBtu ratio } & 0.172 & \\
\hline $\begin{array}{l}2018 \text { regulated evironment and } \\
\text { oppoprtunity cost of oil }\end{array}$ & $\begin{array}{l}\text { Oil }=\$ 6.45 / \mathrm{bbl}, \\
\text { natural gas }= \\
\$ 1.25 / \mathrm{MMBtu}\end{array}$ & $\begin{array}{l}\text { Oil }=\$ 85 / \mathrm{bbl}, \text { natural } \\
\text { gas }=\$ 1.25 / \mathrm{MMBtu}\end{array}$ & $\begin{array}{l}\text { Oil }=\$ 55 / \mathrm{bbl}, \\
\text { natural gas }= \\
\$ 1.25 / \mathrm{MMBtu}\end{array}$ \\
\hline Cost of crude oil power plant (\$/MWh) & 11.34 & 149.47 & 96.71 \\
\hline $\begin{array}{l}\text { Cost of simple cycle natural gas power } \\
\text { plant (\$/MWh) }\end{array}$ & 12.94 & 12.94 & 12.94 \\
\hline U.S. LNG (fixed price \$8/MMBtu) & $\begin{array}{l}\text { Oil }=\$ 85 / \mathrm{bbl}, \\
\text { natural gas }=\$ 8 / \\
\text { MMBtu }\end{array}$ & $\begin{array}{l}\text { Oil }=\$ 55 / \mathrm{bbl}, \text { natural } \\
\text { gas }=\$ 8 / \mathrm{MMBtu}\end{array}$ & $\begin{array}{l}\text { Oil }=\$ 35 / \mathrm{bbl}, \\
\text { natural gas }=\$ 8 / \\
\text { MMBtu }\end{array}$ \\
\hline Cost of crude oil power plant (\$/MWh) & 149.47 & 96.71 & 61.55 \\
\hline $\begin{array}{l}\text { Cost of natural gas combine cycle power } \\
\text { plant }(\$ / M W h)\end{array}$ & 61.19 & 61.19 & 61.19 \\
\hline $\begin{array}{l}\text { LNG priced with standard (conservative) } \\
\text { oil indexed clauses }\end{array}$ & $\begin{array}{l}\text { Oil= } \$ 85 / \mathrm{bbl} \text {, } \\
\text { natural gas }= \\
14 \% \text { of oil }+\$ 1 \\
\text { (Shippping and } \\
\text { regas) }\end{array}$ & $\begin{array}{l}\text { Oil }=\$ 55 / \mathrm{bbl} \text {, natural } \\
\text { gas }=14 \% \text { of oil }+ \\
\$ 1 \text { (Shippping and } \\
\text { regas) }\end{array}$ & $\begin{array}{l}\text { Oil= } \$ 55 / \text { bbl, } \\
\text { natural gas }= \\
14 \% \text { of oil }+\$ 1 \\
\text { (Shippping and } \\
\text { regas) }\end{array}$ \\
\hline Cost of crude oil power plant (\$/MWh) & 149.47 & 96.71 & 61.55 \\
\hline $\begin{array}{l}\text { Cost of natural gas combine cycle power } \\
\text { plant }(\$ / M W h)\end{array}$ & 98.67 & 66.55 & 45.13 \\
\hline $\begin{array}{l}2035 \text { WGM market-based price for LNG } \\
\text { imported in Saudi Arabia versus oil price } \\
\text { at } \$ 55 / \mathrm{bbl}\end{array}$ & $\begin{array}{l}\text { Oil }=\$ 55 / b b l \\
\text { natural gas at oil } \\
\text { parity }\end{array}$ & $\begin{array}{l}\text { Oil }=\$ 55 / \text { bbl, natural } \\
\text { gas } \$ 9.47 / M M B t u \\
\text { ( } 6 \text { bcm scenario) }\end{array}$ & $\begin{array}{l}\text { Oil }=\$ 55 / \mathrm{bbl}, \\
\text { natural gas }= \\
\$ 10.05 / \mathrm{MMBtu} \\
\text { (30 bcm scenario) }\end{array}$ \\
\hline Cost of crude oil power plant ( $\$ / M W h)$ & 96.71 & 96.71 & 96.71 \\
\hline $\begin{array}{l}\text { Cost of natural gas combined cycle power } \\
\text { plant }(\$ / \mathrm{MWh})\end{array}$ & 72.53 & 72.44 & 76.87 \\
\hline
\end{tabular}

Sources: EIA https://www.eia.gov/electricity/annual/html/epa_08_02.html; BP Statistical Review 2018; KAPSARC. 
may use its trade experience to divert unwanted cargoes of LNG to such customers. Alongside the benefits outlined above, using LNG for power generation could also help Saudi Arabia meet its environmental and air quality targets.

Saudi Arabia aims to reform energy pricing mechanisms in the energy sector. Importing LNG could lead it toward more resilient energy marketbased pricing in its power generation supply mix. As the Kingdom imports more LNG at international prices, the delivered cost should feed through to domestic markets and facilitate a benchmark price for Saudi gas. This price could also help create a pathway to incentivize the development of the Kingdom's domestic gas reserves.

Historically, low domestic natural gas prices in Saudi Arabia resulted in demand outstripping supply. The government responded by setting limits on gas consumption for different sectors. Importing gas may put domestic gas in competition with LNG for power generation. In such a scenario, domestic natural gas volumes would be developed until their cost equals the Saudi delivered LNG price. This provides a gauge that could be used to avoid overinvesting in domestic natural gas development, especially in non-conventional gas. 


\section{Conclusions}

$\mathrm{D}$ espite its apparent disruptiveness, limited importation of LNG into western Saudi Arabia, especially during the summer months, could be a worthwhile and relatively easy way to improve the energy mix in Saudi Arabia's electricity generation sector. New importers could benefit from the predicted growth of LNG markets in the mid-2020s. Our analysis shows that the global supply of LNG can accommodate large draws of it into Saudi Arabia without a significant rise in landed costs. An increasingly flexible LNG market could help Saudi Arabia achieve its domestic targets for the desired shares of gas and alternative energy in its national energy mix, either through a temporary solution to eliminate oil-fired generation in the near term or to insure against delays in domestic gas supplies, natural gas infrastructure expansion, and renewable energy deployment. Furthermore, introducing LNG into Saudi Arabia could create a framework for gas market liberalization and a local price benchmark to help develop the country's domestic gas market.
The International Maritime Organization (IMO) plans to limit the sulfur content in marine fuels starting in 2020. This could lead to surplus volumes of high sulfur fuel oil (HSFO) in the market, fuel that given the right price - could be used for power generation in Saudi Arabia. Further studies could investigate how LNG might compete economically with HSFO after the IMO's new fuel standards have been implemented. While LNG can displace oil costeffectively, it might not be the optimal solution. The price of LNG imported into Saudi Arabia for power generation could be assessed against the prices of other sources of energy such as domestic gas, renewables and nuclear power. Further research could also look into how additional seasonal storage could make domestic gas infrastructure more efficient. Energy efficiency initiatives have also recently started to take effect, and LNG (or domestic gas) may need to fight for its place in the power mix in a lower-than expected energy demand environment. 
Figure 4. WGM oil and oil products price assumptions.

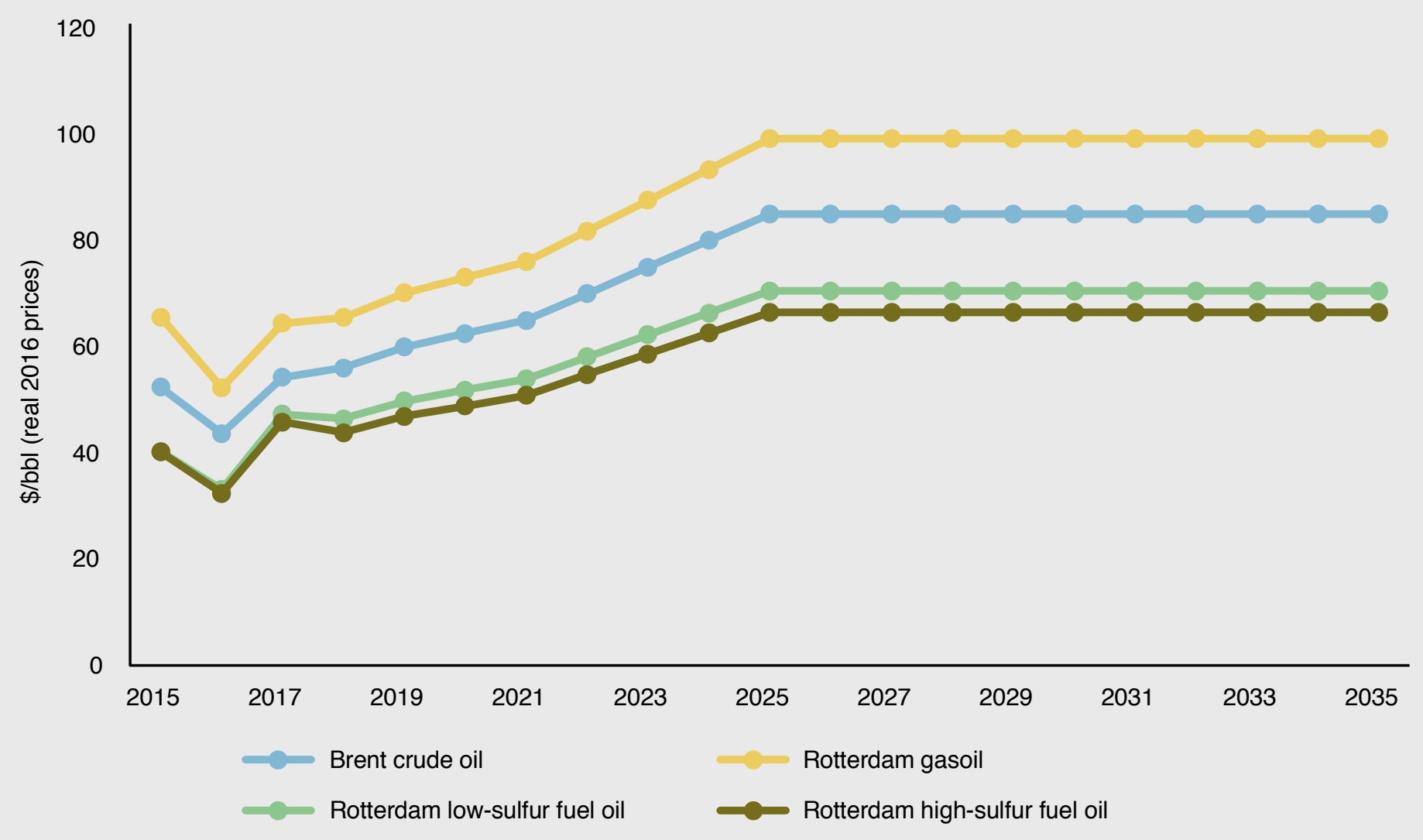

Source: Nexant WGM (March 2018 edition). 


\section{References}

AISaggaf, Hamed. 2018. "Renewable Energy is a Strategic Option for KSA." EU-GCC Clean Energy Technology Network. Accessed November 2018. http://eugcccleanergy.net/sites/default/files/7.\%20 Session\%202_Eng.\%20Hamed\%20Al\%20Saggaf_ Saudi\%20Electricity\%20Company.pdf.

Arab Petroleum Investments Corporation (APICORP). 2018. "Saudi energy price reforms getting serious." February. Accessed October 2018. http://www. apicorparabia.com/Research/EnergyReseach/2018/ APICORP_Energy_Research_V03_N05_2018.pdf

Blazquez, Jorge, Baltasar Manzano, Lester C. Hunt, and Axel Pierru. 2018. "The Value of Saving Oil in Saudi Arabia." KAPSARC discussion paper, Riyadh. https://doi.org/10.30573/KS--2018-DP030

BP. 2018. "BP Statistical Review of World Energy 2018." London, June. https://www.bp.com/en/global/corporate/ energy-economics/statistical-review-of-world-energy.html

Electricity \& Cogeneration Regulatory Authority (ECRA). 2011. "Bringing Demand-Side Management to The Kingdom of Saudi Arabia." Accessed July 2018. https://www.ecra.gov.sa/en-us/ECRAStudies/Documents/ Bringing\%20Demand.pdf

Elass, Jareer. 2018. "Saudi Aramco looks to expand shale gas production" The Arab Weekly, June 17. Accessed Jul. 14, 2018. https://thearabweekly.com/ saudi-aramco-looks-expand-shale-gas-production

Energy Intelligence. 2018. "Aramco Sets Path to Become Gas Exporter." LNG Intelligence, November 27. Accessed December 23, 2018.
IHS Markit. 2017. "IHS Vantage Software."

King and Spalding LLP. 2015. "FSRUs: Looking back at the Evolution of the FSRU Market." Lexology. December 8. Accessed Mar. 5, 2019. https://www.lexology.com/library/detail. aspx?g=964b07cd-2d16-420b-96d4-af47dc2935f2

Marine Traffic. 2018. "Marine Traffic." Accessed June 2018. https://www.marinetraffic.com/en/voyage-planner

Nexant. 2018. "World Gas Model Datasheet." Accessed July 2018. https://www.nexant.com/resources/ world-gas-model-datasheet

Schenckery, Maxime, Rami Shabaneh, Kang Wu, Anne-Sophie Corbeau, Tatiana Mitrova, Tim Boersma, Manfred Hafner, Simone Tagliapietra, and Giovanni Occhiali. 2018. "East Africa Shared Gas Initiative." KAPSARC workshop brief. Riyadh. https://doi:10.30573/ KS--2018-WB12

Songhurst, Brian. July 2017. "The Outlook for Floating Storage and Regasification Units (FSRUs)." Oxford Institute for Energy Studies.

U.S. Energy Information Administration (EIA). 2018. "Average Operating Heat Rate for Selected Energy Sources, 2007-2017." October 22. Accessed February 14, 2019. https://www.eia.gov/electricity/annual/html/ epa_08_01.html

.....2017. "Country Analysis Brief: Saudi Arabia." October 20. Accessed August 30, 2018. https://www.eia.gov/beta/ international/analysis_includes/countries_long/Saudi_ Arabia/saudi_arabia.pdf 


\section{Notes}

(a) 


\section{About the Authors}

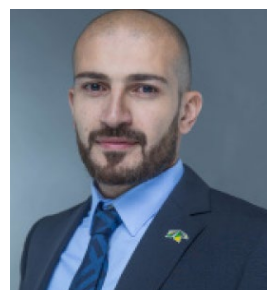

\section{Rami Shabaneh}

Rami is a senior research associate focusing on global gas and liquids markets. He has more than 10 years of research and industry experience in energy market analysis. He holds an M.Sc. in Sustainable Energy Development from the University of Calgary.

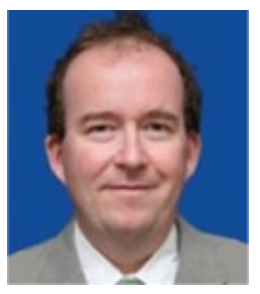

\section{Maxime Schenckery}

Maxime is a visiting researcher at KAPSARC and currently the Director of the Center for Energy Economics and Management at the IFP School. He has over 20 years of experience in the oil and gas industry as a corporate chief energy economist, senior policy adviser and professor. His areas of work encompass oil and gas markets forecasting, energy transition policies and innovation penetration in energy systems. He holds a Ph.D. in Economics from the University of Paris-North.

\section{About the Project}

The objective of this project is to investigate the value that natural gas can provide to the economy of Saudi Arabia, allowing for LNG imports. While developments are underway to increase domestic natural gas production, supplementing domestic supply with LNG imports could be another option for the Kingdom. This project aims to assess this option and its possible consequences. 
INAPSARC

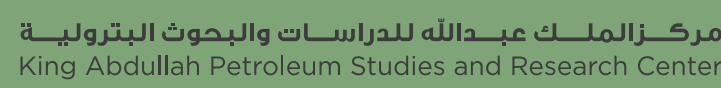

www.kapsarc.org 